\title{
Neural Cell Differentiation of Mesenchymal Stem Cells Isolated from Human Umbilical Cord Blood: In Vitro
}

\author{
Intissar N. Waheed \\ Scientific Research Center \\ University of Duhok \\ E- mail: intissar1960@yahoo.com
}

\author{
Aveen A. Mohammed Ameen \\ Scientific Research Center \\ University of Duhok
}

\section{(Received 17/ 4 / 2011 ; Accepted 20 / 7 / 2011 )}

\begin{abstract}
Human umbilical cord blood derived mesenchymal stem cells (MSCs) are regarded as valuable source for cell transplantation and cell therapy. These cells in their undifferentiated state are fibroblast - like in morphology, and these cells when treated with retinoic acid, or epidermal growth factor, rapidly assumed the morphology of multipolar neurons. The resulting differentiated cells express nestin marker, a neurofilament protein that is one of the most specific markers of multipotent neural stem cells. In conclusion, the present findings support the hypothesis that cord blood contains MSCs that can be induced to differentiate into neuronal pathway and express neuronal marker.
\end{abstract}

Keywords: Umbilical cord blood, Mesenchymal stem cells, Retinoic acid, Epidermal growth factor, In vitro, Neurogenic differentiation.

تمليز الظلايا الجذعية اللحمية المعزولة من م الحل اللسري للإنسل إلل الظلايا المصبية

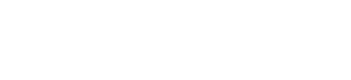

\section{الملغص}

تعد الخلايا الجذعية اللحمية المشقة من دم الحل للسري للإنسان مصدرامهما للفل والعلاج الخلوي.

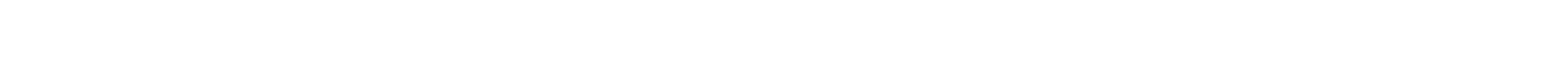

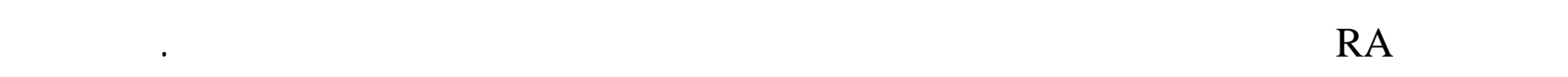

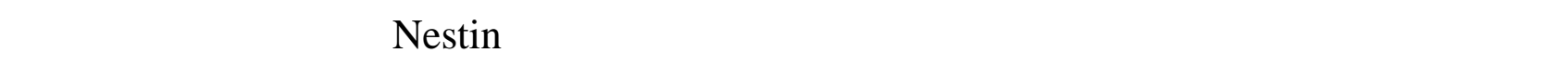

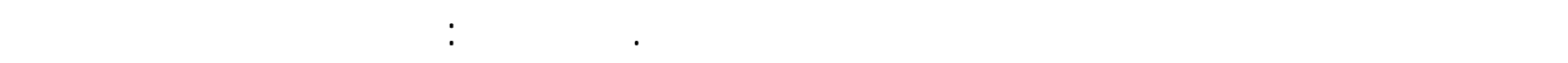

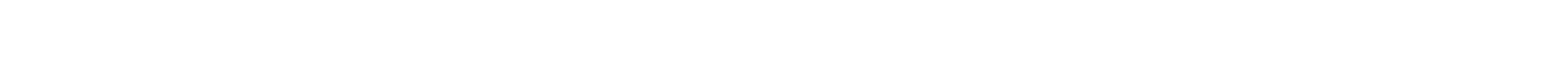
لمظهارها للولم العصبي. 


\section{INTRODUCTION}

Umbilical cord blood (UCB) is an interesting source of hematopoietic stem cells (HSCs) and mesenchymal stem cells (MSCs) for gene therapy (Hao et al., 1995) and cell transplantation and cell therapy (Ju Ah et al., 2004).

The advantages of UCB, as a source of stem cells, include their accessibility, noninvasive sampling and, thus, its safety for potential donors (Broxmeyer, 2005).

Mesenchymal stem cells are referred to stem cells originated mainly from the mesoderm, embedded in mesenchymal tissues and bone marrow (BM), and giving rise to cells of connective tissues, such as bone, muscle, cartilage, fat and tendon (Ju Ah et al., 2004). This means that MSCs are present in virtually all human tissues, including the UCB. UCB-derived MSCs did not differ from MSCs isolated from BM, by main characteristic feature, such as morphology, expression of surface markers and differentiation potential (Musina et al., 2007).

Umbilical cord blood derived MSCs have been proven to differentiate into many types of cells such as astrocytes (Erices et al., 2000; Goodwin et al., 2001), chondrocytes (Lee et al., 2004; Carranico et al., 2008) adipocytes (Goodwin et al., 2001; Lee et al., 2004), skeletal myoblasts (Romanov et al., 2003), hepatocytes (Lee et al., 2004, Kang et al., 2006), and neuroglial cells (Bicknese et al., 2002).

Due to the ability of UCB-derived stem cells to differentiate into neuronal pathways, stem cell offers great hope especially to patients suffering from neurological disorders. Recent studies from different laboratories showed that a neuronal or glial fate could be directed not only from UCB-derived mononuclear cells (MNCs) and its CD34-depleted subpopulation, but also from UCB-derived HSCs and MSCs, suggesting that the neonatal blood system is full of proneurogenic cells (Lee et al., 2004).

The objective of the present study was to obtain expanded culture of MSCs from a mononuclear cell (MNC) fraction of human UCB, then evaluate their in vitro differentiation potential into neural cells, by using growth factor such as Retinoic acid (RA) and Epidermal like growth factor (EGF), then determination of the neural differentiation by using immunocytochemistry procedure by using specific neural marker such as anti- human Nestin (USBio).

\section{MATERIALS AND METHODS}

\section{Separation and culture of human umbilical cord blood derived- mononuclear cells}

Umbilical cord blood samples were obtained mainly from 'Azadi Teaching Hospital in Duhok' after obtaining the mother's informed consent. A blood sample $(20 \mathrm{ml})$ was collected immediately from the umbilical cord (UC) veins after delivery of the baby. The UC clumped, breaking the link between the baby and placenta. Each cord was washed out with antiseptic solution (70\% ethanol, $10 \%$ betadine), then the blood which is withdrawn by syringe while the placenta was still in utero and the cord blood were collected in tubes containing anti-coagulant to keep blood from clotting before it reaches the laboratory. The experimental work of this study was done in Animal Tissue Culture Labl Scientific Research Center\ University of Duhok in 2009-2010. 
Each $10 \mathrm{ml}$ of UCB sample was diluted $1: 1$ with $0.9 \%$ normal saline $(\mathrm{NaCl})$. Then, the diluted blood was layered over an equal volume of lymphocyte separation medium (Ficoll Paque) (a density of $1.077 \pm 0.001 \mathrm{~g} / \mathrm{ml}$ ) (US Biological: USA) and centrifuged at $3000 \mathrm{rpm}$ for 30 min at room temperature (Barkhatov et al., 2008).

After density gradient centrifugation, the resulting MNCs were retrieved from buffy coat layer by pipetting and placed in a10 $\mathrm{ml}$ sterile conical tubes, then washed two to three times with $0.9 \%$ normal saline at $3000 \mathrm{rpm}$ for $10 \mathrm{~min}$ and resuspended in culture medium to a concentration of $1 \times 10^{4} \backslash \mathrm{ml}$.

These cells were cultured in sterile disposable tissue culture flask (25ml) (Nunc; Denemark) in $5 \mathrm{ml}$ of modified eagle medium (MEM) (Sigma: Germany) which prepared according to the manufacturer instruction and supplemented with 10\% fetal calf serum (FCS) (Sigma; Germany) for growth and nourishment, 100 units $\backslash \mathrm{ml}$ penicillin, and $100 \mu \mathrm{g} \backslash \mathrm{ml}$ streptomycin to inhibit bacterial growth, and incubated in CO2 incubator (Lab Tech: Korea), for 3 weeks at $37 \mathrm{C}^{\circ}, 5 \% \mathrm{CO} 2$ and with $50 \%$ of the media being changed every week (Lee et al., 2004).

Cultures were screened continuously by inverted microscope (Zeiss: Germany) to get hold of developing colonies of adherent MSCs.

\section{Neurogenic differentiation of umbilical cord blood - derived mesenchymal stem cells}

To induce neurogenic differentiation, first, the monolayer of MSCs was dispersed with trypsin - EDTA in order to get single cell suspension, second the dispersed MSCs were recultured in multi- well tissue culture plates (4 -wells) (Sterilin LTD: England) at a density of $1 \times 10^{4}$ cells / $\mathrm{cm}$ and divided in three groups as follow:

Group 1: Treated with cultured medium only and referred as a control group.

Group 2: Treated with cultured medium plus $10 \%$ FCS and $0.5 \mu \mathrm{M}$ RA to stimulate the differentiation of MSCs to the neurogenic pathway.

Group 3: Treated with cultured medium plus 10ng $\backslash \mathrm{ml}$ EGF to stimulate the differentiation of MSCs to the neurogenic pathway.

The cultures were maintained at $37 \mathrm{C}^{\circ}, 5 \% \mathrm{CO} 2$ and examined daily by inverted microscope for growth and differentiation.

\section{Immunocytochemical determination of neural marker (anti- human nestin) in the differentiated UCB-MSCs}

After seven days from treatment with growth factor, the differentiated cells in treated groups and non differentiated cells in control group were processed for immunocytochemistry staining by using anti-human nestin marker (US \ Biological) according to the manufacturer's instructions, and counter stained with Harris Hematoxylin. Nestin is an intermediate protein and a well- known specific neural stem cell antigen (Wislet-Gendebien et al., 2005 A \& B) 


\section{RESULTS}

Human Mononucleated cells (MNCs) were isolated from UCB by using density gradient centrifugation; the resulting MNCs were retrieved from buffy coat layer and resuspended in culture medium (Fig. 1).

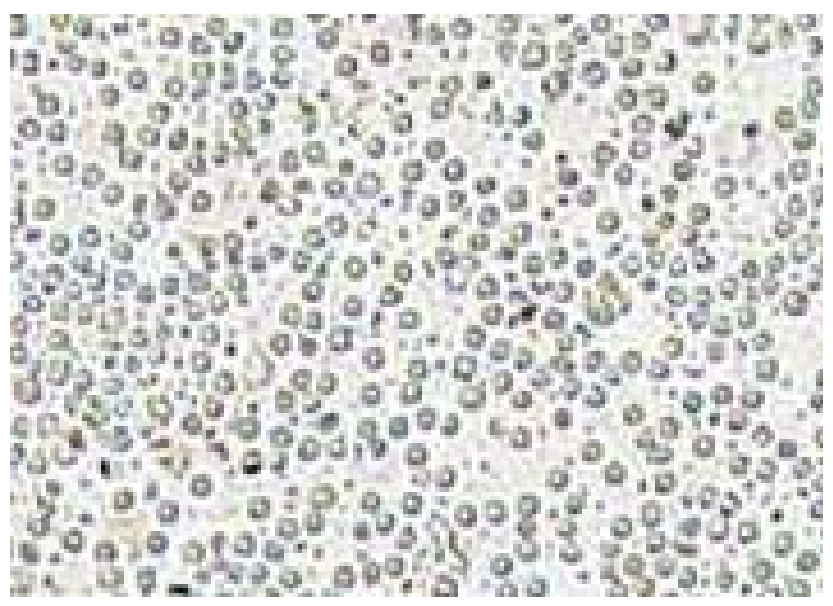

Fig. 1: The morphology of cord blood mononuclear cells isolated from HUCB. (X50).

After plating, the MNCs became attached to the plastic culture flasks and formed adherent cells. The adherent cells began to proliferate, and after seven days of cultivation, numerous fibroblasts like- cells could be observed (Fig. 2). The cells gradually grow for two weeks to form small individual colonies displaying fibroblast - like morphology with short and long processes as well as, small round cells with a high nuclear to cytoplasmic ratio (Figs. 3 \& 4).

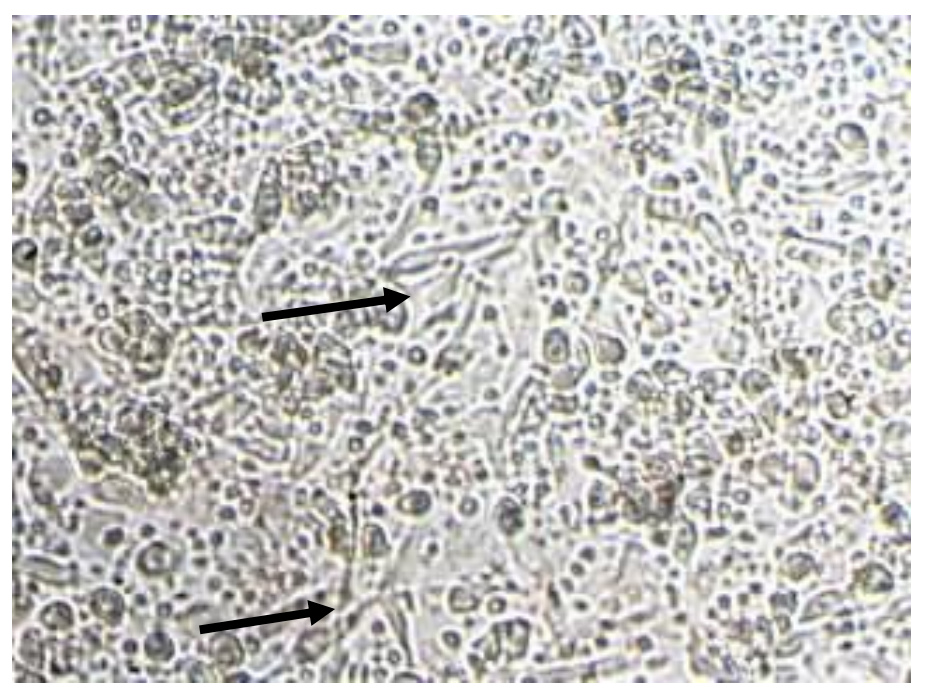

Fig. 2: Showing the attachment and growth of UCB derived MSCs within one week of culture. $(\longrightarrow)$ (X100) 


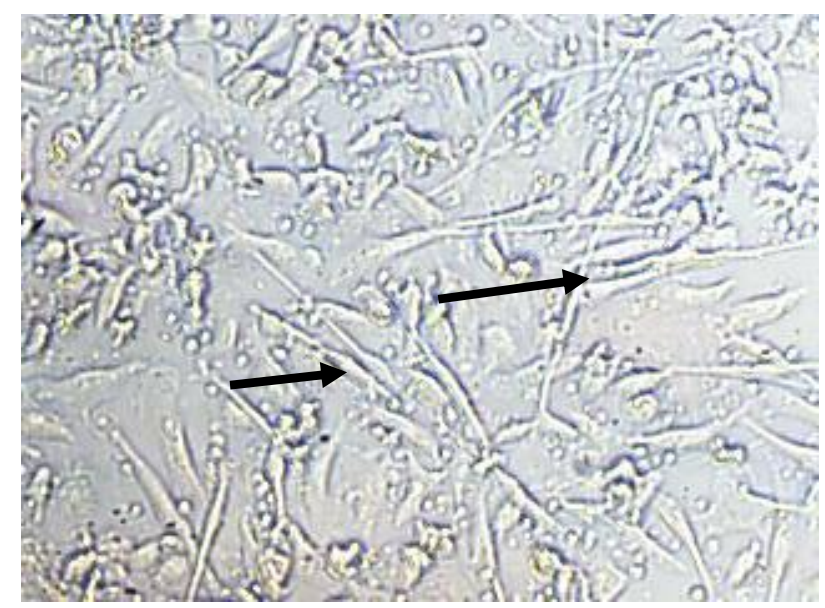

Fig. 3: Two weeks of culture demonstrate the fibroblast - like morphology of MSCs elaborating cytoplasmic processes with short and long processes(bipolar cells) $(\longrightarrow)(\mathrm{X} 100)$.

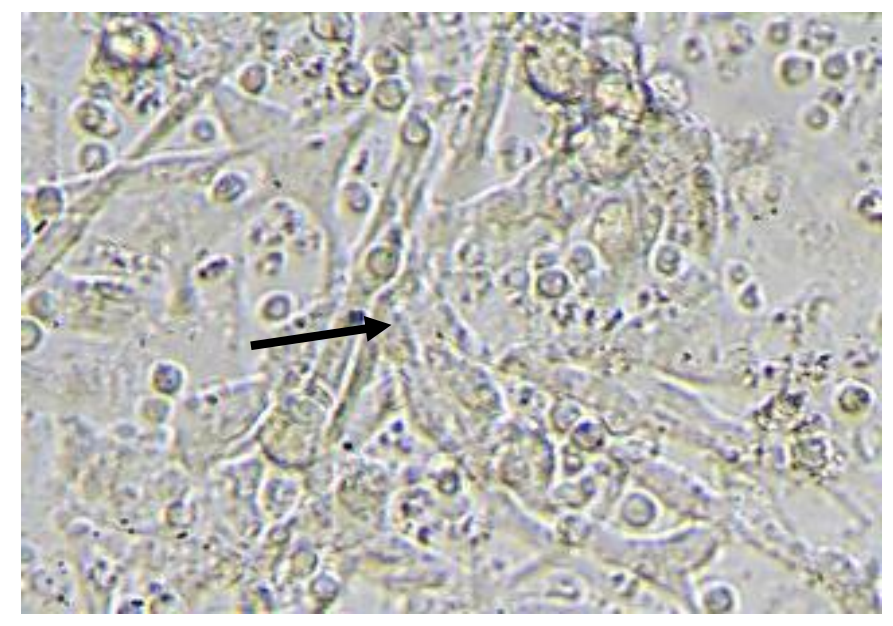

Fig. 4: Demonstrate the morphology of expanded culture of UCB- MSCs $(\longrightarrow$ ) and small round cells after two weeks culture (X200).

Mesenchymal stem cells are characterized by their ability to form colonies comprising spindle - shaped cells derived from a single cell. The number of cellular colonies with different size has obviously increased. In large colonies, cells were more densely distributed and showed a spindle like shape, as growth of cells continued, colonies gradually expanded in size with adjacent ones and interconnected with each other (Fig. 5). By the end of the third week, a homogeneous layer of fibroblastoid- like cells occupied the whole plastic flask surface. 


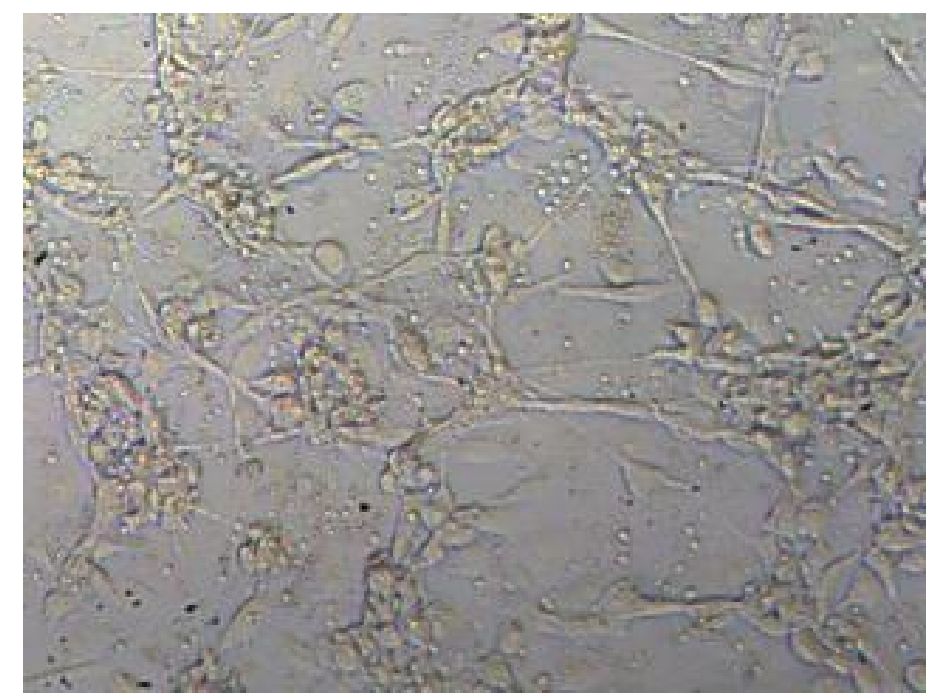

Fig. 5: After $3^{\text {rd }}$ week in culture, demonstrate the MSCs and their colonies which expanded in size and the cells become interconnected with each other. (X100).

\section{Neurogenic differentiation of umbilical cord blood - derived mesenchymal stem cells}

The major characteristic of MSCs is their capacity to differentiate in vitro into different tissues after specific induction. In this study, the differentiation of MSCs derived from UCB into neuronal cells was evaluated by incubation in induction medium (neurogenic medium). These cells were divided in three groups treated with, (RA, EGF and with medium only as a control group). All groups were cultured and maintained for several days.

The response of UCB- derived MSCs to neurogenic stimulants was rapid that dramatic changes in the morphology occurred in most of the cells within one week. The cells in both RA and EGF treatment and control groups began to attach and most of these cells become bipolar and extended long processes, while other cells were rounded. But within the time of culture, morphological changes increased progressively in RA and EGF treated cells, so the cells in the plates assumed the morphology of multipolar neurons (Fig. $6 \mathrm{~B} \& \mathrm{C}$ ). The region around a nucleus became narrower and thicker to form a cell-body-like structure while the rest of cytoplasm was elongated to give rise to multiple cellular processes (Fig. 7 B\&C).

Within two weeks of differentiation, the microscopic examination showed a heterogeneous mixture of cell types ranging from large flat cells with neurotic processes to small spindle shaped cell with fine branching.

The control groups were observed as a monolayer of fibroblastoid cells in undifferentiated state (Fig. 6 A \& Fig. 7 A). 


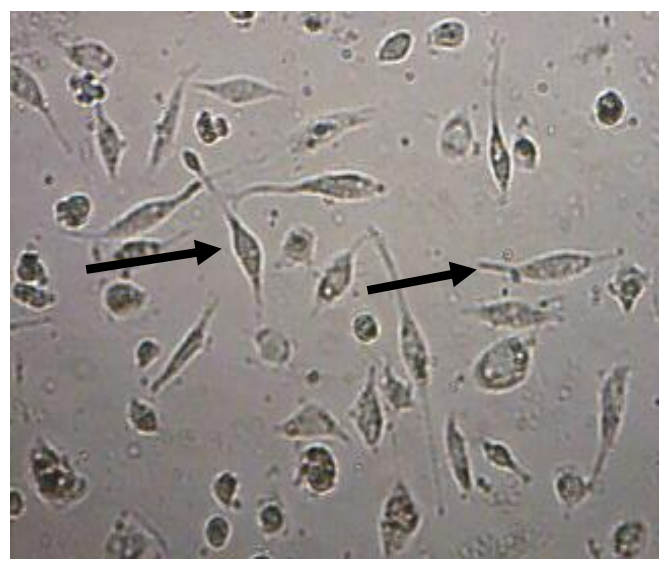

(A)

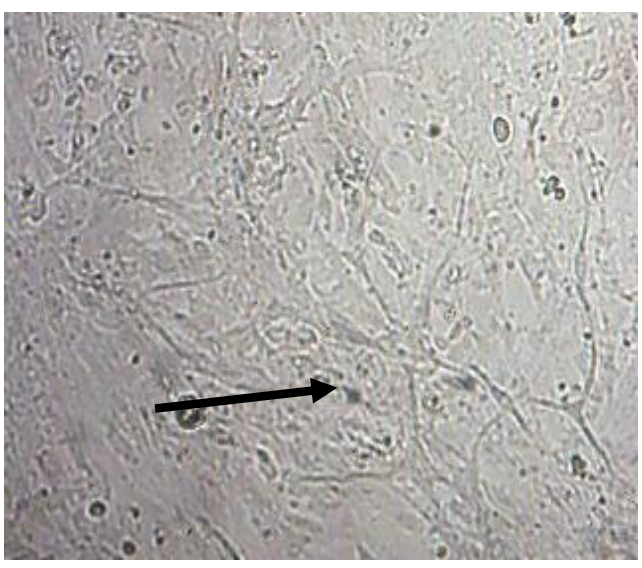

(B)

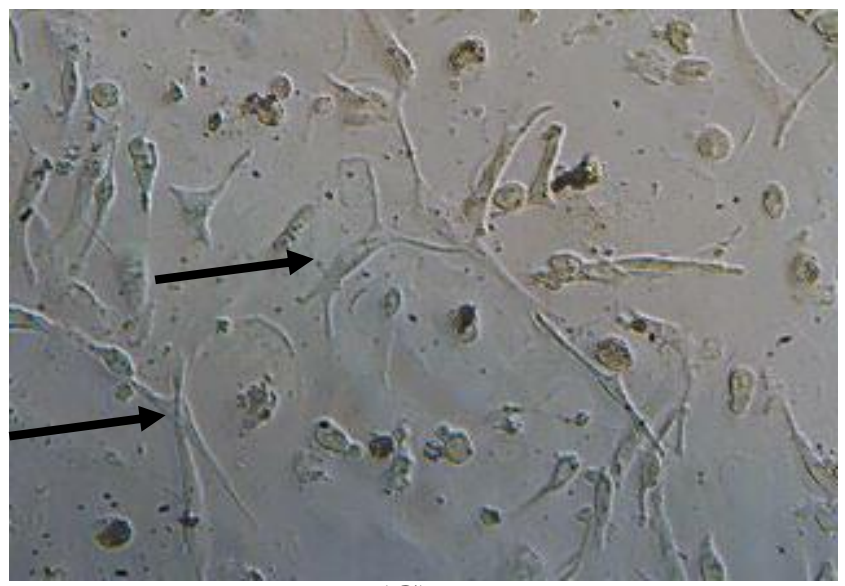

(C)

Fig. 6: In vitro differentiation of UCB-derived MSCs after seven days from treatment with: (A): Culture medium only (Control group), the MSCs appeared spindle in shape and have fibroblast- like morphology $(\longrightarrow)$ (X100).

(B: X50; C X100): Neurogenic differentiation of UCB- derived MSCs after treatment with: RA (B) and EGF (C). The cells appeared with multipolar neuron- like morphology and the most of the cells acquired the morphology of neuroglial cells<smiles>[3H][Te]</smiles> 


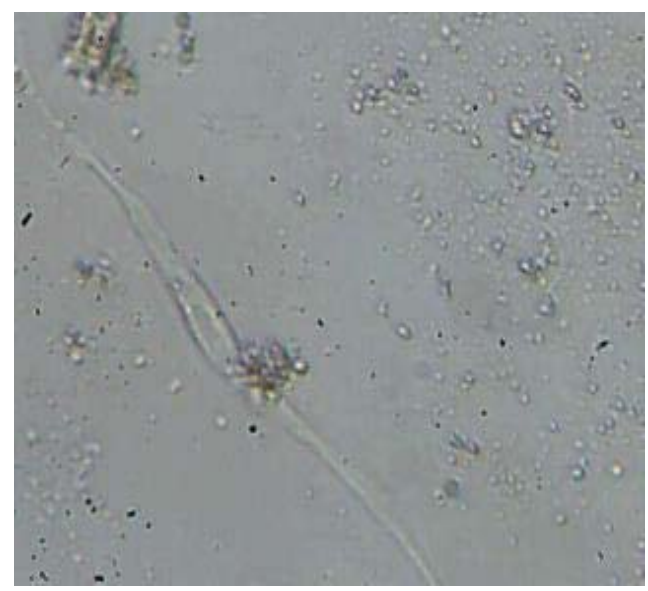

(A)

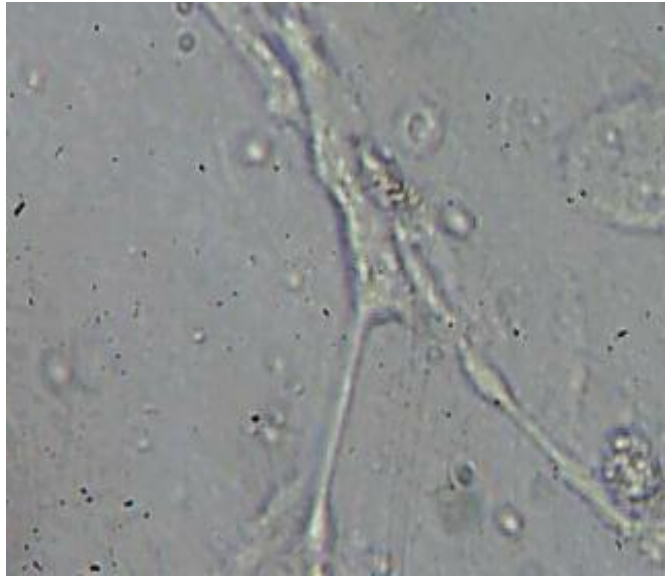

(B)

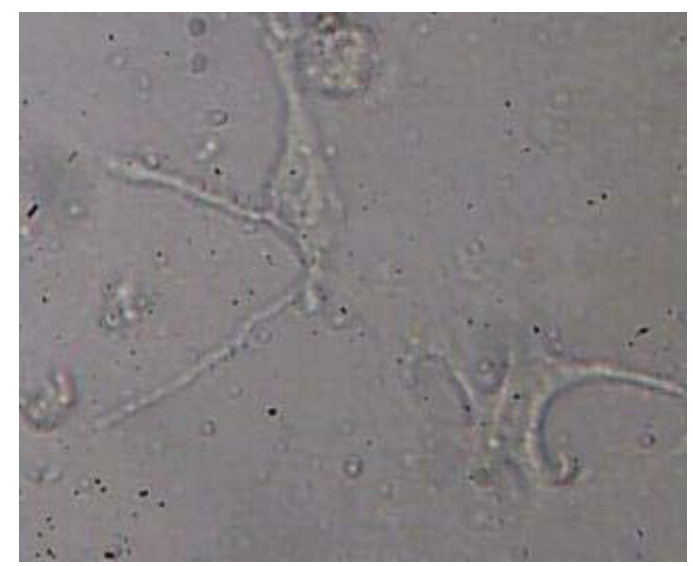

(C)

Fig.7: Higher magnification of the MSC single cell after in vitro differentiation compared with control group. (A): Control group: the cell appeared in spindle shaped (fibroblast-like cell) and this is the normal feature of undifferentiated MSC. While in (B: treated with RA) and (C: treated with EGF) the cell appeared in multipolar neuron-like morphology (X400).

\section{Expression of neuronal marker:}

To evaluate neuronal differentiation capacity of UCB-derived MSCs, the immunocytochemical staining for neural marker (nestin) in the groups treated with RA and EGF showed the staining of 3,3'-diaminobenzidine (DAB) chromogen to be evenly distributed throughout the cytoplasm of cells elaborating long cytoplasmic processes and appeared in brown color (Fig.8 A and B). While the undifferentiated MSCs were not stained with this marker (Fig 9). This result confirmed the neural differentiation of MSCs. 


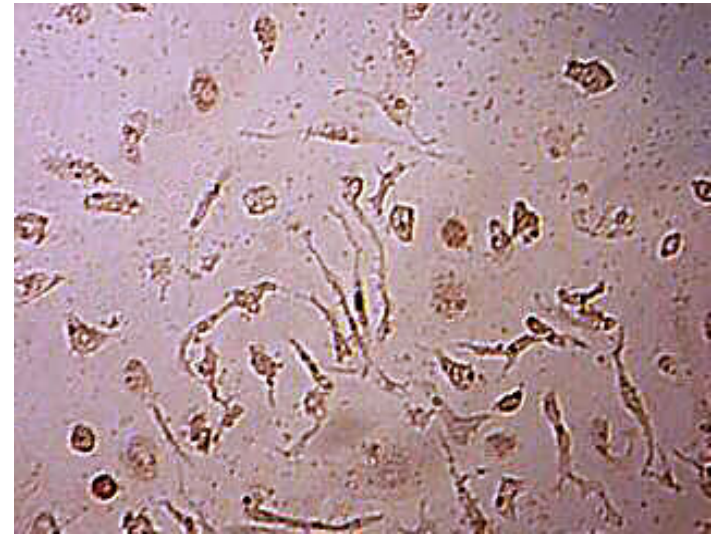

(A)

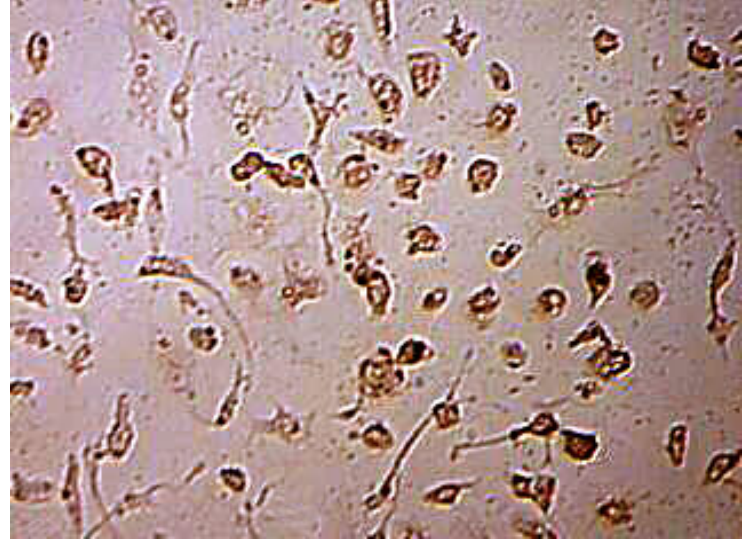

(B)

Fig. 8: Expression of neural marker (nestin marker) on the UCB- derived MSCs after treatment with RA (A) and EGF (B), both of them show the positive immunoreactivity for nestin marker (brown color) and the brown color distributed through the cytoplasm and long processes (X100).

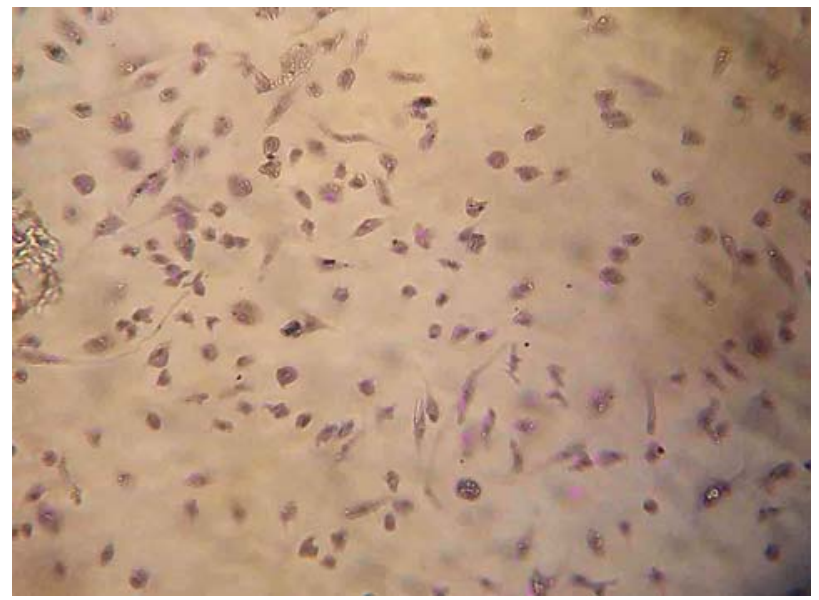

Fig. 9: UCB-derived MSCs (Control group). Show that MSCs were not stained with nestin marker and they give negative result (blue color of counter stain hematoxylin ) (X50).

\section{DISCUSSION}

Human umbilical cord blood is now considered a valuable source for stem cells; this blood is known to contain both HSCs and MSCs. There has been a substantial increase in the clinical use and research investigation of UCB in hematopoietic transplantation and regenerative medicine especially attractive in neural diseases for which no current cure is available (Zhang et al., 2004 ; Bhatia and Hare, 2005 ; Moise, 2005).

From the results of the present study and other studies such as (Goodwin et al., 2001; Minguell et al., 2001; Tasi et al., 2004; Al-Azawwi et al., 2008; Barkhatov et al., 2008), it 
is appeared that, the cultures of plastic - adherent cells provide to be heterogeneous. Two main morphological cell types were discernible, spindle- shaped cells (fibroblast -like cells) that are presumably regarded as MSCs and polygonal cells that are most likely of hematopoietic origin, both of which are regarded as valuable source for cell transplantation. After seven days in the primary culture, numerous fibroblasts -like cells began to divide and formed small individual colonies. Within the time of culture these small colonies continued to proliferate, meanwhile the cells displaying fibroblast - like morphology with short and long processes migrating from these colonies and as demonstrated by Yoon et al., (2001); Al-Azawwi et al., (2008) that MSCs are characterized by their ability to form colonies comprising spindle- shaped cells.

Stem cells have the ability to choose between prolonged self-renewal and differentiation. The fate of choice is highly regulated by intrinsic signal and the external microenvironment, the element of which are being rapidly elucidated. These cells will need to be differentiated or otherwise modified before they can be used clinically (Watt and Hogan, 2000).

Different studies and the present study have been indicated that UCB-derived MSCs can be induced to differentiate into neural cells by using different growth factors. In the developing forebrain, mounting evidence has suggested that the generation of neurons and glia proliferation and differentiation are regulated by extrinsic factors including growth factors and neurotransmitters (Fisher, 1997, Cameron et al., 1998). EGF is one type of the neurotrophic factors and the interest in these substances as reported by Mckay, (1997) is particularly high because they may lead to understanding not only of congenital defects of nervous system development, but also of the involution changes that occur with aging and because they may eventually be used in devising therapies for central nervous system injuries and diseases.

The result of present study showed that when the cells treated with EGF display relatively high potency to expand and to grow differentiated colonies and this agrees with Kojima and Tator, (2000) and Sanchez-Ramos et al., (2001) that the role of EGF in the differentiation are:

- That it acts as mitogen or developmental hormone.

- That it acts as neurotransmitter or neuromodulator or both.

The result of present study indicated that treatment with RA could push UCB-derived MSCs toward the neurogenic differentiation. The role of the RA as mentioned by Chen et al., (1996) RA exerts its function through receptors; homo- or hetrodimers of RAR / RXR complexes bind to RA response elements and cause transcriptional initiation of target genes. Thus it is possible that RAR / RXR complexes interact with genes involved in neuronal differentiation.

Our results also observed by Sanchez-Ramos et al., (2001) who demonstrated that RA and nerve growth factor (NGF) exhibit a change in phenotype of these cells to the neuronal cells and expressed molecular markers usually associated with neurons and glial cells. A study carried by Kogler et al., (2005) showed that UCB cells are able to differentiate into neural cells that express neurofilament and the implantation of these cells into the intact rat brain showed migratory activity and typical neuron- like morphology. In 2009 Mutlak et al. indicated that RA treatment alone could push UCB-derived MSCs toward the neurogenic 
differentiation path to be neuron or glial cells and by using EGF, induced the differentiation of UCB-derived HSCs to differentiate into neuronal precursors.

Immunocytochemistry staining in the present study indicated that untreated cultures were not stained for neuronal markers (nestin marker), while the immunoreactivity to this marker give positive result after treated with RA and EGF, this results also recorded by Ha et al., (2003) who found that more than 60\% of CD133 expressing human cord blood monocytes also express nestin antigen in their cytoplasm, and this result supports the idea that cord blood stem cells can adopt a neuronal fate. Also studies carried out by WisletGendebien et al., (2005, A and B) showed that MSC are able to differentiate into neural cells and thus are able to respond to some neural differentiation stimulating cues encountered in the co-culture as long as MSC express nestin. Nestin is an intermediate filament protein predominantly expressed by neural progenitors (Lendahl et al., 1990). During embryogenesis, nestin is expressed in migrating and proliferating cells, whereas in adult tissues, nestin is mainly restricted to areas of regeneration (Wiese et al., 2004). Moreover, these authors demonstrated that nestin is abundant in embryonic stem cells (ESCs)-derived progenitor cells that have the potential to develop into neuroectodermal, endodermal and mesodermal lineages and represents a specific marker of multi-lineage progenitor cells. Similarly, the analyses of neurospheres obtained from ES cells (which are known to be nestin-negative in vivo) demonstrates that all the cells within those spheres express nestin, suggesting that nestin expression is correlated with the initial step of neural differentiation (Tropepe et al., 2001).

In conclusion, the present findings support the hypothesis that cord blood contains cells that can be induced to change phenotype and express neuronal marker and these specific "neurogenic" cells can be isolated, expanded and these cells might be suitable for transplantation in neurodegenerative diseases, gene delivery to the central nervous system and repair of brain and spinal cord injuries.

\section{REFERENCES}

Al-Azawwi, I.N.W.; Mutlak, B.H.; Kadhim, H.H. (2008). In vitro study of umbilical cord blood- derived mesenchymal stem cells and their neurogenic differentiation. Zanco J. Med. Sci., 12 (Special issue),73-79.

Barkhatov, I.M.; Roumiantsev, S.A.; Vladimirskaya, E.B.; Afanayev B.V. (2008). Composition and functional properties of monolayer cell culture from human umbilical cord blood. C.T.T., 1(2),1-14.

Bhatia, R.; Hare, J.M. (2005). Mesenchymal stem cells: future source for reparative medicin. Le Jacq Communication, Inc., 11(2),87-91.

Bicknese, A.R.; Goodwin, H.S.; Quinn, C.O.; Henderson, V.C.; Chien, S.N.; Wall, D.A. (2002). Human umbilical cord blood cells can be induced to express markers for neurons and glia. Cell Transplant., 11,261-264.

Broxmeyer, H.E. (2005). Biology of cord blood cells and future prospects for enhanced clinical benefit. Cytotherapy., 7,209-218.

Cameron, H.A.; Hazel,H.G.; Mckay, R.D.(1998). Regulation of neurogenesis by growth factors and neurotransmitters. J. Neurobiol., 36,287-306.

Carrancio, S.; Lopez-Holgado, N.; Sanchez-Guijo, F.M.; Villaron, E.; Barbado, V.; Teera S.; Diez Campelo , M.; Blanco, J.; San Miguel, J.F.; Del Canizo, M.C. (2008). 
Optimization of mesenchymal stem cell expansion procedures by cell separation and culture conditions modification. Exp Hematol., 36,1014-1021.

Chen, R.; Clifford, J.; Zusi; C., Starrett, J.; Tortolani, D.; Ostrowski, J.; Reczek, P.R.; Chambon, P.; Gronemeyer, H. (1996). Two distinct actions of retinoid-receptor ligands. Nature., 382,819-822.

Erices, A.; Conget, P.; Minguell , J.J. (2000). Mesenchymal progenitor cells in human umbilical cord blood. Br.J Haematol., 109,235-242.

Fisher, L.J. (1997). Neural precursor cells: applications for the study and repair of the central nervous system. Neurobiol. Dis., 4,1-22.

Goodwin, H.S.; Bicknese, A.R.; Chien, S.N.; Bogucki, B.D.; Quinn C.O.; Wall, D.A. (2001). Multilineage differentiation activity by cells isolated from umbilical cord blood :expression of bone, fat, and neural markers. Biol. Blood Marrow Transplant., 7,581-588

Ha, Y.; Lee, J.E.; Kim, K.N.; Cho, Y.E.; Yoon, D.H. (2003). Intermediate filament nestin expressions in human cord blood monocytes. Acta Neuruchir. 145, 483-487.

Hao, Q.L.; Shah , A. J.; Thiemann, F. T.; Smogorzewska, E.M.; Crooks, G. M. (1995). A functional comparison of CD34+ CD38- cells in cord blood and bone marrow. Blood, 86,3745-3753

Ju, Ah. J.; Eun , J.i.G.; Seung, H. H.; Soo, H. H.; Seong, W. K.; II Ho. Y.; Chiyoung, A.; Hoon, H.; Hoeon, K. (2004). Rapid neural differentiation of human cord bloodderived mesenchymal stem cells. Neuro.Report., 15,1731- 1734.

Kang X-Q.; Zang W-J.; Bao L-J.; Li D-L.; Xu X-L.; Yu X-J. (2006). Differentiating characterization of human umbilical cord blood - derived mesenchymal stem cells in vitro. Cell Bio Int., 30,569-575.

Kogler, G.S.; Senken, J.A.; Airey, A. (2005). Human somatic stem cell from placental cord blood with intrinsic pluripotent differentiation potential. J. Exp. Med., 200,123-135.

Kojima, A; Tator, C.H. (2000). Epidermal growth factor and Fibroblast growth factor cause proliferation of ependymal precursor cells in adult rat spinal cord in vivo. J. Neuropathol. Exper.Neurol., 59,687-697.

Lee, O.K.; Kuo, T.K.; Chen, W.M.; Lee, K.D.; Hsieh, S.L.; Chen, T.H. (2004). Isolation of multipotent mesenchymal stem cells from umbilical cord blood. Blood, 103,6691675.

Lendahl, U.; Zimmerman, L.B.; McKay, R.D.(1990). CNS stem cells express a new class of intermediate filament protein. Cell, 6,585-595.

Mckay, R.(1997). Stem cells in the central nervous system. Science, 276,66-71.

Minguell, J.J.; Erices, A.; Conget, P.(2001). Mesenchymal stem cells. Exp. Biol. Med.,226,507-520.

Moise, K. J. (2005). Umbilical cord blood stem cells. Obst. Gyne., 106,393-407.

Musina, R.A.; Bekchanova, E.S.; Belyavskii, A.V.; Grinenko, T.S.; Sukhikh, G. T. (2007). Umbilical cord blood mesenchymal stem cells. Bull. Exp. Biol. Med.,143,127-131.

Mutlak, B.H.; Kadhim, A. H..H.; Waheed I.N. (2009). In vitro study of umbilical cord blood- derived hematopoietic stem cells and their neurogenic differentiation. $J$. Duhok Univ. 12 (special issue), 178-188. 
Romanov , Y. A.; Svintsitskaya , V. A. ; Smirnov, V. N. (2003). Searching for alternative sources of postnatal human mesenchymal stem cells; candidate MSC- like cells from umbilical cord. Stem Cells, 21,105-110.

Sanchez-Ramos, J.R.; Kamath, S.G.; Zigova, T.; Willing, A.; Pelaez, F.C.; Stedeford, T.; Chopp, M.; Sandberg, P.R. (2001). Expression of neural markers in human umbilical cord blood. Exp. Neurol., 177,109-115.

Tasi, M.S.; Lee, J.L.; Chang, Y.J.; Hwang, S.M. (2004). Isolation of human multipotent mesenchymal stem cells from second-trimester amniotic fluid using a noval twostage culture protocol. Hum. Reprod., 109,1450-1456.

Tropepe, V.; Hitoshi S.; Sirard, C.; Mak, T.W.; Rossant, J.AN.; Van der Kooy, D. (2001). Direct neural fate specification from embryonic stem cells: a primitive mammalian neural stem cell stage acquired through a default mechanism. Neuron, 30,65-78.

Watt, F.M.; Hogan, B.L. (2000). Out of Eden: Stem cells and their niches. Science, 287,1427-1430.

Wiese, C.; Rolletschek, A.; Kania, G.;Blyszczuk, P.; Tarasov, K.V.; Tarasova, Y.; Wersto, P.; Boheler, K.R.; Wobus, A.M. (2004). Nestin expression-a property of multilineage progenitor cells? Cell Mol. Life Sci. 61, 2510-2522.

Wislet-Gendebien, S.; Wautier, F.; Leprince, P.; Rogister, B.(2005 A). Astrocytic and neuronal fate of mesenchymal stem cells expressing nestin. Brain Res. Bull., 68,95102.

Wislet-Gendebien, S.; Hans, G.; Leprice, P.; Rigo, J.M.; Moonen, G.; Rogister, B. (2005 B). Plasticity of cultured mesenchymal stem cells: switch from nestin positive to excitable neuron-like phenotype. Stem cells, 23,392-402.

Yoon, Ha; Joong Uhn, Choi; Do Heum, Yoon; Dong, Soo, Y.; Jean Ju, L.; Hyun, Ok, Kim; Hyun Ok, Kim; Yong Eun, Cho. (2001). Neural phenotype expression of cultured human cord blood cells in vitro. Neuro. Report., 12, 3523-3527.

Zhang Y.; Li C.; Jiang X.; Zhang S.; Wu Y.; Liu B.; Tang P.; Mao N.(2004). Human placenta-derived mesenchymal progenitor cells support culture expansion of long term culture initiating cells from cord blood CD34+ cells. Exp. Hematol., 32,657664. 